\title{
Description of a Housekeeping Program as One of the Occupational Safety and Health Programs at Petrochemical Company
}

\author{
Gambaran Program Housekeeping Sebagai Salah Satu Program Keselamatan dan \\ Kesehatan Kerja di Perusahaan Petrokimia
}

\author{
Rr Sri Rejeki Eviyanti Puspita Sari, Hilmy Ishar Ikhsani \\ Departmentof Occupational Safety and Health, Faculty of Public Health, Universitas Airlangga \\ Campus C Mulyorejo, Surabaya East Java 60115 Indonesia
}

\begin{abstract}
Introduction: Non-fatal accidents are estimated to occur in 374 million cases each year and have serious consequences for the productivity of workers. Petrochemical Company, which is a company that operates in the field of fertilizers and other chemicals, needs to conduct an Occupational Safety and Health (OSH) program, one of which is the Housekeeping program. The purpose of this study is to determine the housekeeping program at Petrochemical Company and the application at Amurea II Plant III of Petrochemical Company. Methods: This research was conducted at Petrochemical Company in June 2017. This study used a cross-sectional design. The variables use were the OSH policy, the housekeeping program, the housekeeping procedures, and the applications of housekeeping. The primary data were obtained through direct observation and the secondary data were obtained from the company's documents. Results: Petrochemical Company has included the housekeeping program in the OSH policy. There are two housekeeping programs at Petrochemical Company, namely daily housekeeping and monthly housekeeping. Also, there are 2 types of procedures in the housekeeping program, namely units that can do the housekeeping program and units that cannot do the housekeeping program. Moreover, the housekeeping program has been implemented in all units, one of which is at Amurea II Plant III Project. Conclusion: The Housekeeping program has been integrated in the company's policy so that the housekeeping program can be done by all workers both daily and monthly. Housekeeping application has also been implemented at Amurea II Plant III of Petrochemical Company.
\end{abstract}

Keywords:housekeeping procedure, housekeeping program, occupational safety and health policy

\begin{abstract}
ABSTRAK
Pendahuluan: Kecelakaan non-fatal diperkirakan terjadi sebanyak 374 juta kasus setiap tahunnya dan memiliki konsekuensi serius terhadap produktivitas pekerjanya. Perusahaan Petrokimia yang merupakan suatu perusahaan yang beroperasi di bidang pupuk dan bahan kimia lainnya perlu melakukan program Keselamatan dan Kesehatan Kerja(K3) untuk menanggulangi masalah tersebut salah satunya yaitu program Housekeeping. Tujuan penelitian ini adalah untuk mengetahui program Housekeeping yang dijalankan di Amurea II Pabrik III. Metode: Penelitian ini dilakukan di Perusahaan Petrokimia pada Juni 2017. Penelitian ini menggunakan desain cross sectional. Variabel penelitian ini adalah kebijakan K3, program Housekeeping, prosedur Housekeeping, dan penerapan Housekeeping. Data yang dipakai merupakan data primer yaitu melalui pengamatan langsung dan data sekunder yaitu dari dokumen perusahaan. Hasil: Perusahaan Petrokimia telah memasukkan program housekeeping pada kebijakan K3 di Perusahaan Petrokimia. Terdapat dua program housekeeping yang ada di Perusahaan Petrokimia yaitu housekeeping harian dan housekeeping bulanan. Prosedur pada program housekeeping juga terdapat 2 jenis yaitu pada unit yang dapat melaksanakan program housekeeping dan unit yang tidak dapat melaksanakan program housekeeping. Program housekeeping telah diimplementasikan pada seluruh unit di Perusahaan Petrokimia salah satunya adalah Proyek Amurea II Pabrik III. Simpulan: Program Housekeeping telah terintegrasi dalam kebijakan perusahaan sehingga program Housekeeping dapat dilakukan oleh seluruh tenaga kerja baik secara harian maupun bulanan. Aplikasi Housekeeping sudah diterapkan di Amurea II Plant III dari Perusahaan Petrokimia.berhubungan dengan produktivitas kerja karena hasil distribusi karakteristik individu dominan hanya pada satu kategori.
\end{abstract}

Kata kunci: kebijakan keselamatan dan kesehatan kerja, program housekeeping, prosedur housekeeping

Corresponding Author:

Rr Sri Rejeki Eviyanti Puspita Sari

Email: rr.sri.rejeki-2018@fkm.unair.ac.id

Telephone: +6285746755449

(C2021 IJOSH All right reserved. Open access under CC BY NC-SA license doi: 10.20473/ijosh.v10i1.2021.105-116 Received November 01, 2019, received in revised form January 18, 2021, Accepted January 19, 2021, Published: April 2021 


\section{INTRODUCTION}

Work accidents are work related incidents which can cause illness, injury, and death (OHSAS, 2007). The Regulation of the Minister of Manpower Number 03/ MEN / 98 states that work accidents are unexpected and undesirable incidents that can cause human casualties and properties (Minister of Manpower, 1998). From these two definitions, it can be said that a work accident is an incident related to work that is unexpected or unwanted and can cause injury or death as well as property loss.

The International Labour Organization (ILO) estimates that every year there will be around 2.78 million workers who die either from work accidents or from work-related diseases. Of this estimate, around 380,000 deaths are due to workplace accidents, which arecategorized as non-fatal accidents and fatal accidents. Non-fatal accidents are estimated to occur as many as $\mathbf{3 7 4}$ million cases each year. This number is almost a thousand times more than the number of fatal accidents. The nonfatal accidents have serious consequences for the productivity of the workers (Hämäläinen et al, 2017).

Work accidents can occur due to unsafe acts and unsafe conditions. One of the possible causes of workplace accidents is the untidy workplace, associated with small accidents such as falling, slipping, stumbling, and being entangled, among many others. An untidy workplace can also make workers do work uncomfortably and unsafely (Simanjuntak dan Praditya, 2012).

To reduce the incidence of small accidents, several companies have implemented a housekeeping program. Housekeeping is one of the company's programs to create a safe and comfortable work environment by storing work equipment properly, removing garbage, and creating a clean and dry workplace. If the standard of housekeeping in the industrial environment is improved, it will have an impact on the reduction of the number of work accidents by $70-80 \%$ (Kurniawati and Yuniarti, 2014).

Petrochemical Company is a company in East Java that operates in the area of fertilizers and other chemicals. Petrochemical Company has 21 factories, consisting of 3 main producers of mainstay fertilizers such as Urea, Phonska, ZA, ZK, and SP36. Petrochemical Company has around 13,000 workers. Because the number of workers at Petrochemical Company and the number of chemicals available at Petrochemical Company are high, Petrochemical Company needs to implement a good OSH program to minimize the risk of work accidents.

Amurea II Plant III is one of the production plants in Petrochemical Company. Amurea II Plant III is a factory that produces Ammonia and Urea which are raw materials for making fertilizers. Because of the large number of chemicals present in Amurea II Plant III, there is a need for a housekeeping program to be implemented to prevent occupational accidents and occupational diseases. The purpose of this study is to describe the housekeeping program at Petrochemical Company and its application at Amurea II Plant III of Petrochemical Company.

\section{METHODS}

This research was an observational research. The data were analyzed using descriptive methods because this study aims to describe the housekeeping program at Petrochemical Company and its application at Amurea II Plant III of Petrochemical Company. The study design used was cross sectional because the research processwas carried out at a certain point in time.

The data were collected at the Department of Health Safety and Environment (HSE) at Petrochemical Company in June 2017. The study used primary data obtained from direct observation and secondary data obtained from Occupational Safety and Health (OSH) documents in the company. The primary data collection used an observation sheet. Moreover, the variables to be examined were the OSH policy, the housekeeping program, the housekeeping procedures, and the application of housekeeping at Petrochemical Company.

\section{RESULTS}

Petrochemical Company realizes that in the work environment there is a potential for accidents or occupational diseases to occur due to employee negligence. Therefore, the company has made some efforts to prevent the work accidents and supervise the employees, and one of the efforts is by implementing the housekeeping program. Based on the results of the study, Petrochemical Company has arranged some strategies related to the success of housekeeping policy. 


\section{Occupational Safety and Health (OSH) Policy at Petrochemical Company}

Petrochemical Company has a commitment regarding the importance of OSH,the environment for the company's growth, and the improvement of employee welfare. For this reason, Petrochemical Company applies OSH policies as a guide in implementing OSH procedures in an effort to prevent or reduce work accidents. The first OSH policy in Petrochemical Company is putting safety, health and the environment as the top priorities in every activity. The second policy is preventing accidents, occupational diseases, and damage to facilities and infrastructure by eliminating or reducing risks through the analysis and control of all potential hazards and enhancing employee competence so as to create a safe work culture and system. The third policy is continuously managing and improving the environment to prevent the significant impacts of environmental pollution by reducing greenhouse gas (GHG) emissions, liquid waste, solid waste, and noise; reducing and utilizing hazardous and non-hazardous waste; protecting biodiversity; conserving water; and implementing Reduce, Recycle, Reuse, Recovery (4R) Principle. The fourth policy is guaranteeing customer satisfaction by providing fertilizer products, chemical products and services at the right quality, right quantity, right type, right place, right time, and right price, ensuring halal compliance with Islamic law and product safety (Food Grade Category) consistently and continuously. The fifth policy is obeying and complying with the laws and other applicable requirements; being responsive to OSH issues, global environment, conservation of natural resources, and energy efficiency; developing a culture of innovation and knowledge sharing; and developing commitment to society by implementing Responsible Care and Corporate Social Responsibility (CSR).

\section{Industrial Housekeeping Program at Petrochemical Company}

Housekeeping at Petrochemical Company has been integrated in the company's policy, which is a procedure for implementing cleanliness and tidiness in the company's work environment. This policy is formulated by the Department of Environment and Occupational Safety and Health of the company. This policy was signed and received approval from the Head of Human Resources on November 12, 2007.
The housekeeping program at Petrochemical Company is divided into daily programs (every day) and monthly programs (once a month) by cleaning the area with the principle of Sort, Set, Shine, Standardize, and Sustain (5S) in each unit at Petrochemical Company. A housekeeping policy at Petrochemical Company has arranged the rules and instructed all parties to always maintain tidiness and cleanliness of the workplace. The management and policies on cleanliness and tidiness of the workplace are internal company's policies and are concrete in the scope of the company.

\section{Daily Housekeeping Program}

Daily Housekeeping Program is a housekeeping program that must be carried out by every employee up to the contractor in daily work activities in the Petrochemical Company area. All employees of Petrochemical Company collect everything that is still needed and get rid of unnecessary items, to facilitate the use of goods. In addition, in an effort to keep goods from being scattered, workers at Petrochemical Company also store items according to their layouts and according to their labels. To keep the work environment clean, employees at Petrochemical Company clean the environment of Petrochemical Company both indoors and outdoors every day.

The OSH inspection officers and maintenance department in each unit at Petrochemical Company carry out work area maintenance with the help of third parties. They also report the fulfilment of facilities and infrastructure in the work area to meet the needs of the workers.

\section{Monthly Housekeeping Program}

Monthly Housekeeping Program is a housekeeping program which is carried out on the 5 th of every month with the parties concerned. Petrochemical Company assesses the housekeeping activities in each unit in the Petrochemical Company area. This activity is carried out by a housekeeping team consisting of OSH representatives in each unit, employee representatives in each unit, and $\mathrm{OSH}$ officers. The housekeeping team does the recording and reporting with the assessment form listed in the appendix. Petrochemical Company gives a social award and a symbol to units that have been assessed on their housekeeping program. The social award is done by giving a symbol in the form of a three-star flag placed in the unit. 
The award and symbol are given by Petrochemical Company based on several criteria. The assessment criteria for each unit are different according to the conditions and works of the unit. Units that do the housekeeping program perfectly will get a white gold star. Meanwhile, units that do the housekeeping program well will get a green white star. And the units that run the housekeeping program poorly will get a black flag without star.

\section{Housekeeping Procedures at Petrochemical Company}

\section{Housekeeping's Scope}

This procedure applies to all facilities and infrastructure owned by Petrochemical Company including buildings, machinery, equipment, and supporting infrastructure, including gutters, roads, parks, green lanes, and tank areas and their equipment.

\section{Housekeeping Responsibilities}

Personnel responsible for housekeeping are those who are involved in the area where the work is carried out. These personnel are responsible for the cleanliness and safety of the work during the period the work is carried out, so that workers get a guarantee for work safety while working. The intended personnel are the unit leader, OSH officers in related units, the supervisor, and all workers at Petrochemical Company.

\section{Housekeeping Procedures}

Petrochemical Company implements several procedures in the housekeeping program. The procedures of this housekeeping program must be followed by all units in Petrochemical Company. The first procedure in implementing the housekeeping program is that the housekeeping service requests the unit to submit a Request for Procurement of Services (RPS) or Fault Report (FR) to the housekeeping unit to maintain the cleanliness of the work area, which needs housekeeping services. Next, the housekeeping unit conducts an FR evaluation. Afterwards, the evaluation is assessed on whether the unit can carry out its own housekeeping program or not.

Housekeeping can be done by the units themselves. However, some units cannot do housekeeping programs themselves. For the units that can work on their own housekeeping program, the first procedure is that the housekeeping unit conducts housekeeping in accordance with the FR by issuing a Work Order (WO). Work realization (material usage, man hour, assistive devices, etc.) is stated in the WO document. Furthermore, when the housekeeping is finished, the housekeeping unit changes the status of the Work Order to Work Done until Reported. If the user's unit has received the work, the user's unit (the housekeeping service requestor) changes the Work Order status to Finished.

For housekeeping work that cannot be done by the units themselves (the FR cannot be done due to insufficient budget), the housekeeping unit informs the user work unit (requesting housekeeping services) that the FR cancellation is carried out, and the housekeeping organizing work unit reallocates the budget. In the case of housekeeping work done by partners or outside parties due to limited resources (manpower, materials, tools, skills), the recipients and evaluators are the Maintenance Department I, Maintenance Department II and Maintenance Department III in each working area of Plant I, working area of Plant II, and Unit III of Factory III. Maintenance Department III receives and evaluates the working area of the Department of distribution region I. Department of Health Service Centre (HSC) receives and evaluates the working area of HSC. The Jakarta representative department receives and evaluates the working area of the Jakarta representative department. Breeding Research Staff conducts reception and evaluation for greening and gardening work.

Furthermore, the RPS or FR Recipient and Evaluation Work Unit set forth the results of the evaluation including the scope of work and the estimated costs required for RPS and FR. Then, the Procurement Unit conducts the process of procuring housekeeping services in accordance with applicable regulations. After the partners or outsiders have finished the work, the housekeeping service requesting service coordinates with related work units to conduct joint inspection and report the results into the Minutes of Joint Inspection Results (FM-30-0123). If based on the Minutes of Joint Examination Results, service work is accepted, then the work unit of the official minutes of issuance publishes the Minutes of Handover of Services between Petrochemical Company with Associates or outside parties using FM-30-0026. For service work that cannot be accepted, partners or outsiders are asked to complete the work so that it complies with the contract requirements. 


\section{Implementation of Housekeeping at Petrochemical Company}

The application of housekeeping is very important for accident prevention and for the minimization of company losses. Based on the observations at Petrochemical Company, Petrochemical Company has implemented mandatory housekeeping according to the specified program and applicable regulations.

\section{Daily Housekeeping}

Workers at Petrochemical Company do housekeeping in their daily activities. Workers at Petrochemical Company separateany items that are still needed and get rid of items or objects that are no longer needed to facilitate the use of goods, and this activity has been done in the work area every day. Then, to keep things neat and not scattered at work, workers at Petrochemical Company store equipment or goods in accordance with the layout and labelling or marking that has been implemented in the area of Petrochemical Company. Furthermore, the daily cleaning of Petrochemical Company's

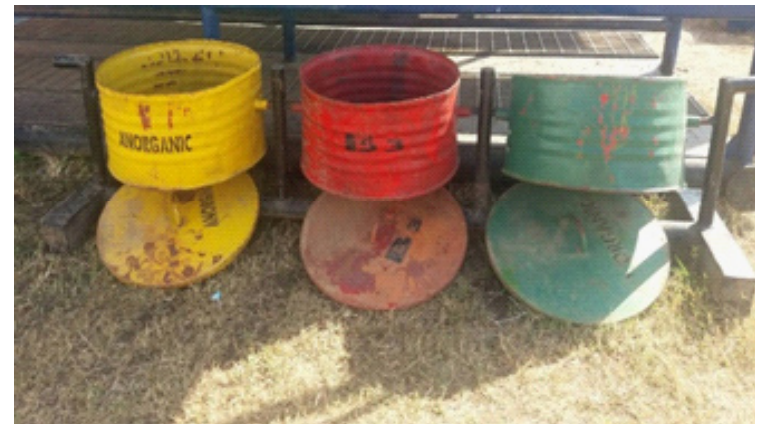

Figure 1. Garbage dumps at Amurea II Plant III of Petrochemical Company in 2017

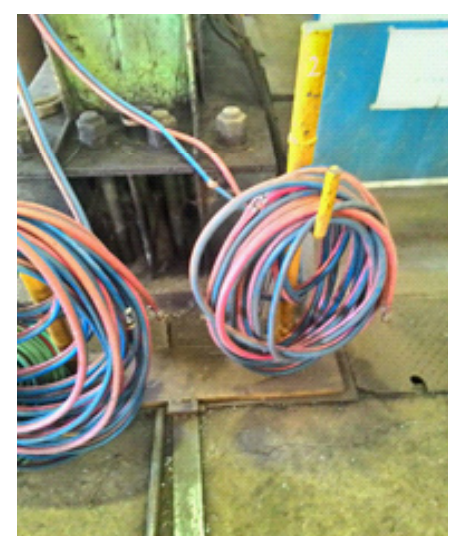

Figure 2. Cable Placement at Amurea II Plant III of Petrochemical Company in 2017 environmental area is carried out by janitors in the scope of Petrochemical Company's areas both indoors and outdoors in the morning at $07.00 \mathrm{WIB}$ and in the afternoon at 15.00 WIB. Meanwhile, daily work area maintenance is carried out by $\mathrm{OSH}$ inspection officers and maintenance officers at each work unit, where in its implementation it is usually carried out by the assistance of a third party or contractor. Reporting on the fulfilment of facilities and infrastructure in the work area can be done by anyone, both Petrochemical Company and the contractor to the unit's OSH officer based on the unit head's consideration. Meanwhile, in the safety briefing activities at work, OSH officers also mention the importance of housekeeping activities to workers. Safety briefing is carried out before the workers start any work.

\section{Monthly Housekeeping}

The application of monthly housekeeping is more focused on the assessment of the sustainability of the activities of housekeeping in each unit area. Monthly housekeeping is performed by a housekeeping team composed of representatives of OSH in each unit, representatives of employees in each unit and OSH officers. Meanwhile, the recording and reporting of montly housekeeping is done by a team of housekeeping, using ratings. Social awards are given to units that have been assessed by giving symbols in the form of a threestar flag placed in the unit. Specifically, a white flag with a gold-coloured star image is associated to perfect criteria of housekeeping, a green flag with white star is associated to good criteria of housekeeping, and a black flag without star is associated to poor criteria of housekeeping.

\section{Application of Housekeeping at Amurea II Plant III of Petrochemical Company}

A housekeeping program has been implemented in all units at Petrochemical Company. One of the units at Petrochemical Company is Amurea II Plant III. Amurea II Plant III has implemented housekeeping in its work activities. To maintain a clean, safe and comfortable working environment, Amurea II Plant III carries out waste management. In waste management activities, Amurea II Plant III requires workers to dispose waste in the trash that has been provided. Workers are also required to sort out the type of waste and dispose it in the appropriate trash bin. Yellow trash cans are for inorganic rubbish (plastic / glass drinking bottles, cans, plastic bags, 


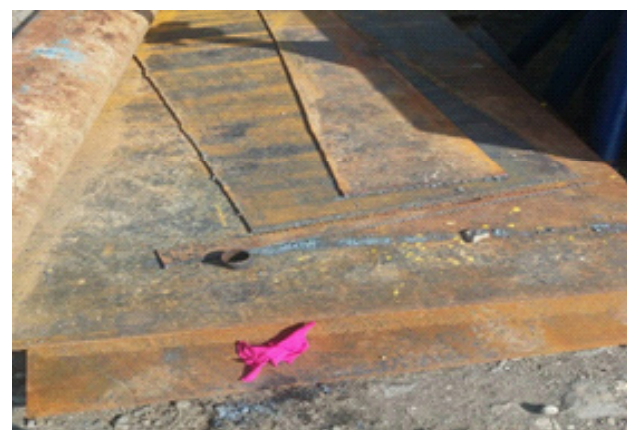

Figure 3. Welding Area at Amurea II Plant III of Petrochemical Company in 2017

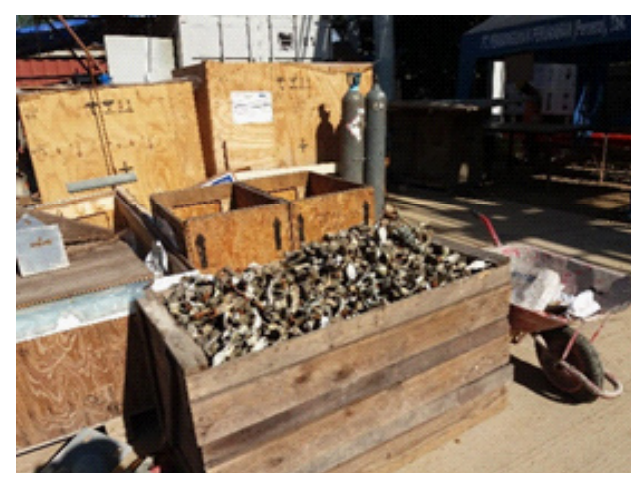

Figure 4. Goods Storage Area at Amurea II Plant III of Petrochemical Company in 2017

etc.). Red trash cans are for hazardous and toxic (B3) waste. Meanwhile, green trash cans are for organic rubbish. In addition, every worker at Amurea II Plant III take turns in throwing garbage in the garbage dump into the landfill. The next process is processing waste that has been classified as recycled waste.

The number of rubbish bins in the Amurea II Plant III is sufficient. All bins in the Amurea II Plant III have lids made of non-combustible material, and the garbage is always disposed properly every working hour.

Electric welding is a work equipment of industrial companies at Petrochemical Company. Most of the work done at Petrochemical Company is related to welding equipment. To prevent accidents due to this welding activity, the Amurea II Plant III has implemented a number of housekeeping programs, such as the placement of cables and welding areas.

In the cable placement activities, Amurea II Plant III requires its workers to tidy up the welding cables. The welding cables must be neatly wound in the same winding direction to prevent the cables from being twisted. Besides, the cable reel is placed at a distance away from sources of ignition or sparks.

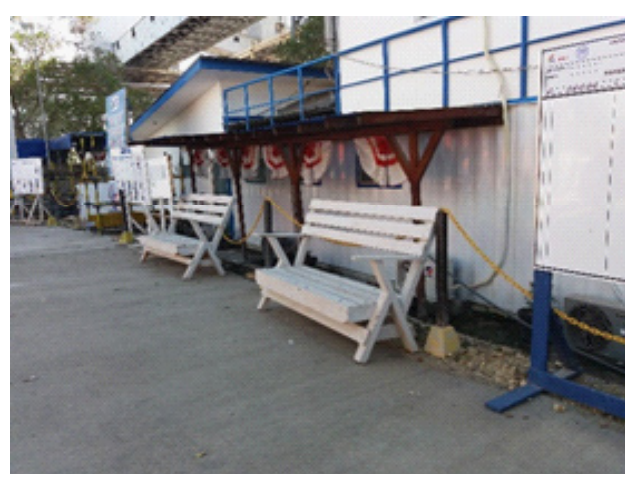

Figure 5. Camp Area at Amurea II Plant III of Petrochemical Company in 2017

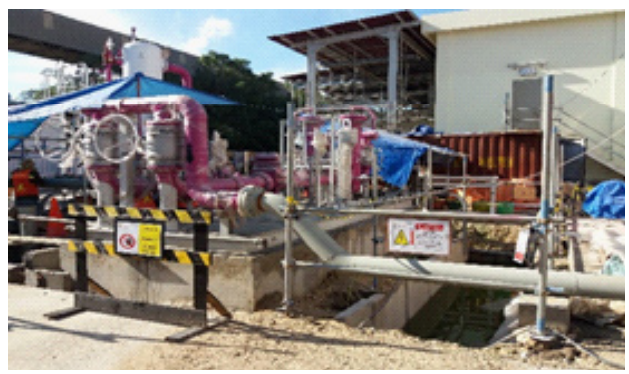

Figure 6. Installation of Symbols and Signs at Amurea II Plant III of Petrochemical Company in 2017

Welding wires are also coiled according to the type and function of each welding cable.

Amurea II Plant III has its own welding area. So, every worker who will do the welding can do it in one place. This welding site is a place used to work on welding of irons in the area of Factory III of PT X. Thus, while doing the welding work, the workers must do it at this welding site so that danger can be isolated and the work looks neat and clean. Moreover, the welding transformers must be placed in accordance with the groups that have been set.

Another application of the housekeeping program at Amurea II Plant III is the placement of items or equipment needed at Petrochemical Company. To prevent work accidents due to scattered objects, Amurea II Plant III has a storage area for goods.

The storage area is very neat. There is no pile of unorganized materials., and allequipment fits into one place. No heavy objects are placed or put on the wall, and no items cover the doors or windows. Moreover, all electrical devices are wrapped safely. The wall is also in a clean conditionas there are no hanging objects that are easy to fall and there is no source of danger on the wall. 
The Amurea II Plant III also requires its workers to rest during recess. Therefore, Amurea II Plant III provides a camp area. Camp area is the location of workers to rest. The camp area must be guarded and cared for hygiene to prevent any diseases. For this reason, the safety officer conducts a structured supervision through a reporton the scope of the resting area. This report is carried out once a week by the safety officer and is given to their leader for follow up.

In the camp area, the condition of the floor is safe and clean. There are no holes, cracks, and corrugation on the floor. There are no layers of ceramics that are detached and no splatter of oil, water and splinters of iron and wood.

Moreover, the quality of food in the camp is in good condition. The food is always covered, and there is an expiration date. The amount of food is also always sufficient, and the refrigerator is in good condition.

Amurea II Plant III also provides lockers for workers. Personal property must be stored in a locker, not in the work area. Lockers should always be cleaned and checked once a week to prevent the accumulation of goods that can lead to unhealthy conditions.

In addition, toilets at Amurea II Plant III is very clean and tidy. Basic necessities such as hand washing soaps and napkins or tissues are available. There is no standing water and clogged drains. The toilets also function well, and once every three days they are cleaned with disinfectant. The lighting inside the toilets is good, and the condition of the wall floor and platform is also in good condition.

Amurea II Plant III also has several areas that have high electric voltage. In those areas there are symbols or signs marking the danger of high voltage. Generators are also always available to facilitate the work by supplying the electrical power during a power outage.

\section{DISCUSSION}

\section{Occupational Safety and Health (OSH) Policy at Petrochemical Company}

Petrochemical Company has already had an OSH policy because the company has awareness on various dangers that might arise in the company enevironment. OSH policies are important for all companies to prevent workplace accidents that might be experienced by their workers. This is consistent with the opinion of Fridayanti and Kusumasmoro (2016) which states that the purpose of the OSH policy is that employees get a guarantee of occupational safety and health physically, socially, and psychologically.

In addition to protecting its workers, the $\mathrm{OSH}$ policy owned by Petrochemical Company also strives to protect the environment. The factory will produce waste, and the factory has an obligation to treat the waste first so as not to pollute the environment around the factory. Petrochemical Company has made efforts to reduce, recycle, reuse, and recovery (4R) waste through waste treatment. This is consistent with previous research conducted by Nasir, Saputro, and Handayani (2015) stating that efforts to treat waste products can be done by reducing, reusing, and recycling the waste.

\section{Industrial Housekeeping Program at Petrochemical Company}

Housekeeping is a program to create a work environment that is safe, comfortable and conducive. A good work environment will also affect worker productivity. This is in line with previous research conducted by Lestari and Trisyulianti (2017) which states that working environment control can increase work productivity ). Another research also states that the magnitude of the influence between the work environment and employee work productivity is 27.7\% (Senata, Nuridja and Suwena, 2014).

Petrochemical Company has implemented a unified standard systemin the process of preparing, planning, and implementing a housekeeping program. This housekeeping program is integrated in the form of documents, which have been set together and are used as a standard in dealing with tidiness and cleanliness.

According to the Minister of Manpower Regulation No. PER.05 / MEN / 1996, in an effort to create a culture of occupational health and safety, there needs to be commitment from companies and workers (Minister of Manpower, 1996). Improved occupational safety and health will be effective if all parties in the company are encouraged to participate in the application and development of the OSH Management System and have a corporate culture that supports and contributes to the OSH Management System. (Tampubolon, 2015). With the integration of the housekeeping program in the company policy, it is expected that this housekeeping system will be able to be implemented by all workers. 


\section{Daily Housekeeping Program}

The Daily Housekeeping program also helps check facilities needed by workers. The fulfillment of facilities will increase worker satisfaction. This is in accordance with previous research conducted by Pangarso, Firdaus and Moeliono (2016) which states that the fulfillment of work facilities has a positive effect on increasing job satisfaction (. Besides, fulfilling work facilities also improves the performance of workers. This is in line with previous research conducted by Anam and Rahardja (2017) which states that the fulfillment of work facilities has an effect on employee performance. Another study conducted by Thomas, Rorong and Tampongangoy (2017) also states that there is an influence of work facilities on employee performance of 0.837 , which is classified as a very strong influence.

\section{Monthly Housekeeping Program}

Petrochemical Company also gives awards for units that have done housekeeping programs according to the category (perfect, good, or poor). This is done by Petrochemical Company with the aim of increasing employee morale and performance in carrying out housekeeping. According to previous research conducted by Irawanti (2016), reward is the most dominating variable in influencing employee performance (Irawanti, 2016). Another study has also shown that the distribution of rewards influences work productivity (Saputra, Nurlina and Hasan, 2017). It is shown that reward provides an increase in the work productivity of employees of PT. Kereta Api Indonesia (Persero) Regional Division II of $217.6 \%$.

\section{HousekeepingProcedures}

\section{Housekeeping Scope}

All facilities and infrastructure at Petrochemical Company are within the scope of housekeeping program because workers who are at Petrochemical Company will use all of the facilities and infrastructure to work. If the facilities and infrastructure are in an untidy and unorganized condition, it will increase the risk of accidents to workers. This is consistent with previous research done by Transiska (2015) that states that one of the triggers for workplace accidents is due to scattered work equipment. Another study by Martiwi, Koesyanto and Pawenang (2017) has also shown that the work environment has a significant effect on workplace accidents at PT Putri Midai. This is further supported by Winarto, Denny and Kurniawan (2016) suggesting that the condition of the work environment has a significant relationship with workplace accidents.

\section{Housekeeping Responsibilities}

All workers at Petrochemical Company is responsible for the housekeeping program. Responsibilities that are owned by workers will improve their performance of workers in carrying out work or responsibility. It is also expected that the housekeeping program can run continuously. This is consistent with previous research done by Yusuf (2018) which states that if worker's responsibilities increase, the worker's performance will also increase (Yusuf, 2018). Another research done by Lokbere, Soegoto and Walangitan (2017) also states that responsibility significantly influences performance ). Meanwhile, Barok, Muktiningsih and Vivanti (2018) further supports this notion b by stating that there is a positive relationship between commitment and responsibility with performance.

\section{Housekeeping Procedures}

Procedures for implementing housekeeping are divided into two. The first procedure is the implementation of housekeeping for units capable of carrying out housekeeping and the second procedure is the implementation of housekeeping for units that have not been able to carry out housekeeping. This is done by Petrochemical Company to keep the housekeeping program running even though the unit cannot do housekeeping on its own. Units that cannot carry out their own housekeeping program are units that do not have sufficient resources. Meanwhile, to conduct a program, sufficient resources are needed. This is consistent with the opinion that resources are needed for the application of the OSH program and to achieve the program's goals (OSHA, 2016). Another opinion says that the OSH program must have sufficient resources (time, funds, staffing) for the program to develop (Labor Occupational Health Program, 2010).

\section{Implementation of Housekeeping at Petrochemical Company}

In its application, the housekeeping program has been carried out by workers both in a daily and monthly basis. Housekeeping program is expected to be able to reduce work accidents caused by unsafe conditions. This is in accordance with previous research conducted by Siregar (2014) which shows 
that that there is a significant relationship between housekeeping and minor accidents. Another previous research done by Christian (208) further states that $5 \mathrm{~S}$ evaluation is needed in efforts to prevent accidents and increase productivity.

\section{Daily Housekeeping}

Housekeeping activities are discussed every day during the safety briefing. This is a good effort to remind workers about the housekeeping program every day. Safety briefing is an effort of informing OSH programs run by companies to workers. This is in accordance with previous research done by Marchamah and KH (2017), which states that OSH socialization is carried out every day through safety briefings. With the socialization, workers' knowledge about the OSH program will increase and the behavior of workers in accordance with the Standard Operating Procedure (SOP) will also increase. Ramadani (2018) in her research states that there is a strong correlation between knowledge and behavior in applying SOP 2018). This is in accordance with the statement of Prabawati, Mifbakhuddin and Prasetio, (2019), which states that there is a relationship between knowledge and worker compliance in implementing SOP.

\section{Monthly Housekeeping}

The implementation of monthly housekeeping focuses on program sustainability as well as recording and reporting of the activities. Recording and reporting activities be done for each program. This is in accordance with previous research in Makassar Haji Hospital which requires recording and reporting of the $\mathrm{K} 3$ implementation program (Ibrahim et al., 2017). The recording and reporting system is also implemented by PT. Angkasa Pura II (Persero) Bandung on all K3 programs (Yuliani and Kurniawan, 2015). The recording and reporting system is needed in order to evaluate the effectiveness of the program. A study by Lii, Pinontoan and Kawatu (2019) states that reporting relevant and timely information must be established to ensure that the occupational safety and health program is monitored and has improved performance.

\section{Application of Housekeeping at Amurea II Plant III of Petrochemical Company}

In implementing housekeeping, Amurea II Plant III of Petrochemical Company has provided trash cans in each unit. The provision of waste bins is done as an effort to have workers throw garbage in the trash and not pollute the work place. This is in line with previous research done by Lii, Pinontoan and Kawatu, (2019),which states that the availability of good waste disposal facilities increases the behavior of disposing waste in the trash cans by 5.87 times.

In addition, there is a change in waste disposal from the temporary dumpsite to landfill as an effort to create a sense of responsibility towards cleanliness to all workers. Moreover, the garbage will be recycled. Based on previous research conducted by Triwardani and Sarmini (2013), one of the efforts to show care for the environment is by recycling waste. This shows that Petrochemical Company in this study also cares about the environment.

Other housekeeping applications that are carried out at one of the units at Amurea II Plant III of Petrochemical Company is tidying the welding cables. The welding cables are tidied by being rolled up in one direction to prevent welding cables from being wrapped around one another. Keeping the welding cable away from the place that has the potential to produce a fire as an effort to prevent fire is also a good strategy. Welding wires are also rolled according to their types and uses to make it easier for workers in doing their work. The cable tidying activity needs to be done because if the cables are left untidy, it will increase the risk of work accidents. This is in line with previous research done by Wulandari and Widajati (2017), which states that the risk of work accidents due to a broken cable is priority 3 as it often occurs in the workplace

Amurea II Plant III of Petrochemical Company also provides a special welding area so that all welding activities are concentrated in one area. This is done as an effort to isolate the dangers that occur so as not to spread to other places. The welding area provided is clean, and there is no visible scattering of equipment. The welding area is also in an open area and is wide enough to facilitate workers in doing welding work and reduce the risk of accidents. The dangers of welding work are caused by the condition of the welding area that is messy and the welding room that is narrow and closed (Bakhtiar and Sulaksmono, 2013).

Furthermore, the camp area is a resting place for Amurea II Plant III of Petrochemical Company. This area can be used by all workers, so it is important to maintain the cleanliness and neatness of this area. Safety Inspector officers supervise and report on the 
condition of the camp area as an effort to maintain the cleanliness and neatness of the condition of the camp area including the food. Food in the camp area can be said to be in good condition. Consumption of good food can help workers get a good nutrition so that they can produce optimal productivity. This is in line with previous done by Farikha and Ardyanto (2016), which states that there is a relationship between good nutrition and productivity.

Good Storage Area Conditions at Amurea II Plant III of Petrochemical Company is also in a neat and clean condition. There are no objects scattered or hanging on the wall at risk of falling and harming workers. In addition to reducing the risk of accidents to workers, the goods storage area makes it easy for workers to find items needed for work.

Moreover, the condition of toilets at Amurea II Plant III of Petrochemical Company are already in a clean and non-slippery condition. The condition of the toilet also needs to be considered to reduce the risk of workers being slipped on the toilet and to reduce the number of accidents in Amurea II Plant III of Petrochemical Company. Another previous study conducted by Yuantari and Nadia (2018) says that $3.6 \%$ of janitors almost slip because of slippery bathroom floors. ).

The next housekeeping application at Amurea II Plant III of Petrochemical Company is the installation of symbols and signs in places that are dangerous or have a high electrical voltage. This needs to be done in the company as a sign for workers to be careful when working in these locations and to make the unauthorized workers not approach the location. According to BSI 5499, the safety signs consist of five categories. The first category is the Prohibition Sign, which aims to tell people who see the sign not to do things that are prohibited because it can cause fatal accidents. The second category is Mandatory Sign, which aims to give orders for workers to be in safe condition by using personal protective equipment in accordance with the hazards that exist in the work environment. The third category is the Danger Sign, whichindicates conditions that are very close to danger and if not avoided can cause death or serious injury. The fourth category is Safety First / Emergency Sign, which is used to convey general instructions relating to safe work practices, remind appropriate safety procedures, and indicate the location of safety equipment. The fifth category is Fire Sign, which aims to provide information about the location of fire extinguishers (British Standard Institute, 1996).

\section{CONCLUSION}

Petrochemical Company has integrated the Housekeeping program in the company policy prepared by the Department of Occupational Safety and Health. The housekeeping program can be done by all workers both in a daily and monthly basis. Moreover, the implementation of the housekeeping program has been carried out by workers at Petrochemical Company. The application of the housekeeping program at Amurea II Plant III of Petrochemical Company is done through waste management, cable placement, camp area procurement, centralized welding location, good storage area procurement, and installation of safety signs.

\section{ACKNOWLEDGEMENTS}

I am grateful to all people whom I have had the pleasure to work with during the accomplishment of this research and other related projects. Each of the members of Occupational Safety and Health Department in Public Health Faculty Universitas Airlangga has provided me extensive personal and professional guidance and taught me new knowledge and skills about both scientific research and life in general.

\section{REFERENCES}

Anam, K. and Rahardja, E. (2017) 'Pengaruh Fasilitas Kerja, Lingkungan Kerja Non Fisik dan Kepuasan Kerja Terhadap Kinerja Karyawan (Studi pada Pegawai Dinas Perindustrian dan Perdagangan Provinsi Jawa Tengah)', Diponegoro Journal of Management, 6(4), pp. 1-11.

Bakhtiar, D. S. and Sulaksmono, M. (2013) 'Risk Assessment Pada Pekerjaan Welding Confined Space Di Bagian Ship Building Pt Dok Dan Perkapalan Surabaya', The Indonesian Journal of Occupational Safety and Health, 2(1), pp. 52-60.

Barok, A. H., Muktiningsih and Vivanti, D. (2018) 'Hubungan Komitmen dan Tanggung Jawab Lingkungan Terhadap Kinerja Pengelola Hutan pada Program Reboisasi', Jurnal Green Growth dan Manajemen Lingkungan, 7(2), pp. 91-100.

British Standard Institute (1996) Safety Sign Regulation. British: Brady.

Christian, R. S. (2018) 'Penerapan Evaluasi Ringkas, Rapi, Resik, Rawat, Rajin PT. INKA (PERSERO) Madiun', The Indonesian Journal of Occupational Safety and Health, 7(1), pp. 11-19. 
Farikha, R. R. P. and Ardyanto, D. (2016) 'Produktivitas Pekerja Sorting Dan Packing', The Indonesian Journal of Occupational Safety and Health, 5(1), pp. 71-80.

Fridayanti, N. and Kusumasmoro, R. (2016) 'Penerapan Keselamatan Dan Kesehatan Kerja Di PT Ferron Par Pharmaceuticals Bekasi', Jurnal Administrasi Kantor, 4(1), pp. 211-234.

Hämäläinen et al (2017) Global Estimates of Occupational Accidents and Work-Related Illnesses 2017. Singapore: Workplace Safety and Health Institute.

Ibrahim, H. et al. (2017) 'Gambaran Penerapan Standar Manajemen di Rumah Sakit Umum Daerah Haji Makassar', Al-Sihah: Public Health Science Journal, 9(2), pp. 160-173.

Irawanti, A. (2016) Pengaruh Pemberian Reward dan Punishment Terhadap Kinerja Karyawan (Studi Kasus pada BMT Lima Satu Sejahtera Jepara). Undergraduate Thesis. Semarang: Faculty of Islamic Economics and Business. Universitas Islam Negeri Walisongo Semarang.

Kurniawati, E. and Yuniarti, R. (2014) 'Springbed dengan Metode Hazard Identification and Risk Assessment (HIRA) (Studi Kasus : PT . Malindo Intitama Raya, Malang, Jawa Timur)', Jurnal Rekayasa dan Manajemen Industri, 2(1), pp. 11-23.

Labor Occupational Health Program (2010) The Whole Worker. Los Angeles: Commission on Health and Safety and Workers Compensation.

Lestari, T. and Trisyulianti, E. (2017) 'Pengaruh Keselamatan Dan Kesehatan Kerja (K3) Terhadap Kinerja Karyawan PT. Haleyora Powerindo Pekanbaru', Jom Fisip, 3(2), pp. 399-404.

Lii, G., Pinontoan, O. R. and Kawatu, P. A. T. (2019) 'Gambaran Penerapan Standar Pelayanan Keselamatan dan Kesehatan Kerja Rumah Sakit (K3RS) di RSUD Datoe Binangkang Kabupaten Bolaang Mongondow', Jurnal KESMAS, 8(6), pp. 536-543.

Lokbere, P., Soegoto, A. S. and Walangitan, M. D. (2017) 'Pengaruh Konflik Kerja dan Tanggungjawab Kerja Terhadap Kinerja Karyawan pada PT. Bank Papua Pusat Jayapura Kota Provinsi Papua', Jurnal Riset Ekonomi, Manajemen, Bisnis, dan Akutansi, 5(3), pp. 4195-4204.

Marchamah, D. N. S. and KH, O. W. (2017) 'Komitmen Kebijakan, Penerapan SMK3, Pengetahuan, dan Sikap K3 terhadap Penggunaan APD Perusahaan Jasa Bongkar Muat', Public Health Perspective Journal, 2(3), pp. 270-278.
Martiwi, R., Koesyanto, H. and Pawenang, E. T. (2017) 'Faktor Penyebab Kecelakaan Kerja pada Pembangunan Gedung', Higeia Journal of Public Health Research and Development, 1(4), pp. 61-71.

Minister of Manpower (1996) PER 05/MEN/1996 Tentang Sistem Manajemen Keselamatan dan Kesehatan Kerja. Jakarta: Minister of Manpower.

Minister of Manpower (1998) Nomor 03 Tahun 1998 Tentang Tatacara Pelaporan dan Pemeriksaan Kecelakaan. Jakarta: Minister of Manpower.

Nasir, M., Saputro, E. P. and Handayani, S. (2015) 'Manajemen pengelolaan limbah industri', Jurnal Managemen dan Bisnis, 19(2), pp. 143-149.

OHSAS (2007) Occupational Health and Safety Management Systems-Requirements.

OSHA (2016) Recommended Practices for Safety and Health Programs in Construction.

Pangarso, A., Fajar Firdaus, F. and K. Moeliono, N. (2016) 'Pengaruh Fasilitas Kerja Terhadap Kepuasan Kerja Karyawan Divisi Sumber Daya Manusia dan Diklat PT. Dirgantara Indonesia', Jurnal Administrasi Bisnis, 12(1), pp. 50-62.

Prabawati, D. I., Mifbakhuddin, M. and Prasetio, D. B. (2019) 'Kepatuhan Pekerja Ketinggian dalam Melaksanakan Standard Operasional Procedure', Jurnal Kesehatan Masyarakat Indonesia, 14(2), p. 29.

Ramadhani, R. P. (2018) 'Hubungan Pengetahuan, Sarana Prasarana, dan Pengawasan dengan Perilaku Penerapan SOP Pekerja Confined Space', International Journal of Occupational Safety and Health, 7(1), pp. 91-101.

Saputra, D., Nurlina and Hasan, L. (2017) 'Pengaruh Reward (Penghargaan) dan Punishment (Sanksi) Terhadap Produktivitas Kerja Karyawan PT Kereta Api Indonesia (persero) Divisi Regional II Sumatera Barat', Jurnal Manajemen dan Kewirausahan, 8(1), pp. 1-4.

Senata, I. W., Nuridja, I. M. and Suwena, K. R. (2014) 'Pengaruh Lingkungan Kerja Terhadap Produktivitas Kerja Karyawan UD. Kembang Sari Kabupaten Bandung Tahun 2012', Jurnal Pendidikan Ekonomi Undiksha, 4(1), pp. 1-10.

Simanjuntak, M. R. A., dan Praditya, R. (2012) 'Identifikasi Penyebab Risiko Kecelakaan Kerja pada Kegiatan Konstruksi Bangunan Gedung di DKI Jakarta, Jurnal Ilmiah MEDIA ENGINEERING, 2(2), pp. 85-99.

Siregar, D. I. S. (2014) Faktor-Faktor yang Berhubungan dengan Kecelakaan Ringan di PT Aqua Golden Mississippi Bekasi Tahun 
2014. Undergraduate Thesis. Jakarta: Faculty of Medicine and Health Science. Universitas Islam Negeri Syarif Hidayatullah.

Tampubolon, L. J. (2015) 'Efektivitas Pengawasan Keselamatan dan Kesehatan Kerja Oleh Dinas Sosial dan Tenaga Kerja Kabupaten Sidoarjo sebagai Upaya Mewujudkan Budaya K3', Kebijakan dan Manajemen Publik, 3(3), pp. 34-43.

Thomas, Y. A., Rorong, A. J. and Tampongangoy, D. (2017) 'Pengaruh Fasilitas Kerja Terhadap Kinerja Pegawai Negeri Sipil di Kantor Dinas Pendidikan Minahasa Tenggara', Jurnal Administrasi Publik, 3(46), pp. 1-10.

Transiska, D. (2015) 'Pengaruh Lingkungan Kerja Dan Faktor Manusia Terhadap Tingkat Kecelakaan Kerja Karyawan Pada Pt. Putri Midai Bangkinang Kabupaten Kampar', Jurnal Online Mahasiswa Fakultas Ekonomi Universitas Riau, 2(1), pp. 1-15.

Triwardani, R. and Sarmini (2013) 'Sampah Di Desa Duwet Kecamatan Bendo Kabupaten Magetan', Kajian Moral dan kewarganegaraan, 3(1), pp. 470-484.

Winarto, S., Denny, H. M. and Kurniawan, B. (2016) 'Studi Kasus Kecelakaan Kerja pada Pekerja Pengeboran Migas Seismic Survey PT. X di Papua Barat', Jurnal Promosi Kesehatan Indonesia, 11(1), p. 51.
Wulandari, D. and Widajati, N. (2017) 'Risk Assessment Pada Pekerja Pengelasan Perkapalan Dengan Pendekatan Job Safety Analysis', The Indonesian Journal of Occupational Safety and Health, 6(1), pp. 1-15.

Yuantari, C. and Nadia, H. (2018) 'Analis Resiko Keselamatan dan Kesehatan Kerja Pada Petugas Kebersihan di Rumah Sakit', Faletehan Health Journal, 5(3), pp. 107-116.

Yuliani, N. and Kurniawan, B. (2015) 'Analisis Pendokumentasian Sistem Manajemen Keselamatan Dan Kesehatan Kerja Berdasarkan Pp No. 50 Tahun 2012 Di Pt Angkasa Pura Ii (Persero) Bandung', Jurnal Kesehatan Masyarakat (e-Journal), 3(3), pp. 545-554.

Yulida, N., Sarto, S. and Suwarni, A. S. (2016) 'Perilaku Masyarakat dalam Membuang Sampah di Aliran Sungai Batang Bakarek-Karek Kota Padang Panjang Sumatera Barat', Berita Kedokteran Masyarakat (BKM Journal of Community Medicine and Public Health), 32(10), pp. 373-378.

Yusuf, N. (2018) 'Kedisiplinan Dan Kerjasama Terhadap Kinerja Pegawai di Universitas Gorontalo', Gorontalo Development Review, 1(1), pp. 15-28. 